\section{Endomycorrhizae and Growth of 'Sweetheart' Strawberry Seedlings}

\author{
Amal de Silva ${ }^{1}$ and Keith Patterson ${ }^{2}$ \\ Department of Horticulture, University of Arkansas, Fayetteville, AR 72701
}

James Mitchell ${ }^{3}$

Department of Biology, Ball State University, Muncie, IN 47306

Additional index words. Fragaria, Glomus intraradices, spore density

\begin{abstract}
Growth of strawberry (Fragaria xananassa Duch. 'Sweetheart') seedlings inoculated with six spore levels ranging from 0 to 12,000 spores/plant of the mycorrhizal fungi Glomus intraradices Schenck and Smith was studied in the greenhouse and with greenhouse plants subsequently moved to the field. Plant height, leaf area, and number of leaves increased significantly with inoculum spore densities ranging from 750 to 12,000 spores/plant in relation to control plants in the greenhouse and field. In the greenhouse, there was a linear relationship between percent infection and spore density, although the relationship was cubic in the field. In the field study, control plants were infected with indigenous mycorrhizae, but inoculated plants produced more runners than the control plants, and foliar $\mathrm{Cu}$ and $\mathrm{Ca}$ increased linearly with increased spore density. Inoculated plants contained significantly more dry matter than the controls. For inoculated plants, root dry weight increased linearly with increased spore density. We conclude that a minimum spore density of $\mathbf{7 5 0}$ spores/plant is sufficient for a positive growth response.
\end{abstract}

Strawberry parent selection for breeding programs focuses on traits such as fruit size, flesh firmness, color, disease resistance, and yield. The breeder selects promising parents, conducts controlled crosses, and achenes are germinated in greenhouses and subsequently planted in the field. Some plants may not be selected due to seedling death or poor growth, which may be related to soilborne diseases, insufficient nutrients, nematodes, and poor root growth in seedling establishment (Maas, 1984).

Vesicular-arbuscular mycorrhizae (VAM) improve plant growth through increased uptake of $\mathrm{P}$, reduction of soilborne diseases (Maronek et al., 1981), increased plant vigor and survival (Solbrig, 1981), and reduced transplant injury (Menge, 1982). Inoculation of seedlings with mycorrhizal fungi resulted in increased plant growth of tomato (Lycopersicon esculentum Mill.) (Daft and Nicolson, 1969), increased runner formation (Holevas, 1966), or more flowers and fruit (Daft and Okusanya, 1973) in strawberry. Although soils may naturally contain VAM (Khan, 1972), stimulation of growth by indigenous mycorrhizae may not be sufficient for significant growth response (Powell, 1981). Daft and Nicolson (1966) noted that initially low spore-count concentration stimulated the host less than more concentrated inoculum. Although other studies have shown growth stimulation by inoculation with mycorrhizal

Received for publication 18 Aug. 1995. Accepted for publication 23 May 1996. The cost of publishing this paper was defrayed in part by the payment of page charges. Under postal regulations, this paper therefore must be hereby marked advertisement solely to indicate this fact.

${ }^{1}$ Graduate Student.

${ }^{2}$ Associate Professor

${ }^{3}$ Assistant Professor.

HortScience, Vol. 31(6), OCtober 1996 and one-half of the sand-spore mixture was mixed with sterilized sand (1:1), and a new set of pots was filled with this mixture. As earlier, sorghum seeds were grown for 6 months in a manner to ensure maximum spore production.

Determination of spore concentration. Random samples of the spore-sand mixture were taken from seven pots mixed thoroughly and bulked to ensure uniformity. A 50-g sample was subjected to wet-sieving and decanting (Gerdemann and Nicolson, 1963) to separate spores from root pieces. The volume of the sand-water mixture was recorded and $5 \mathrm{~mL}$ of this mixture was placed in a petri dish marked with 1-cm grids and the number of spores per 10 squares was counted. From this, the number of spores per original volume was calculated. An average of three samples was taken to determine the spore concentration in the sand inoculum.

Treatments. The experiment was conducted in the greenhouse and in the field using six treatments and four replications in a randomized complete-block design. The treatments consisted of inoculum mixture consisting of spores, sand, and root pieces placed into $25 \times$ $25 \times 5$-cm flats. On the basis of 50 seedlings/ flat, inoculum mixtures were adjusted to produce six spore densities (SD): 0, $750 \pm 36$, $1500 \pm 72,3000 \pm 145,7500 \pm 362$, and 12,000 \pm 579 spores/seedling. For each flat, the remaining volume was filled and mixed with Sunshine No. 2 peat (Fissions Horticulture, Mississauga, Ont., Canada) for a sand : peat ratio of $1: 2,1: 1,2.5: 1,9: 1$, and $25: 1$ for each treatment. The control treatment consisted of no spores, but had the same proportion of sand : peat mix corresponding to each treatment. For all treatments, Osmocote (17N-9P-13K) slow-release fertilizer was added at $0.2 \mathrm{~g} \cdot \mathrm{L}^{-1}$.

Seeds (100) of the homozygous strawberry 'Sweetheart' (Park Seed, Greenwood, S.C.) were planted in trays on 30 June 1992 and were subsequently thinned to 50 seedlings/tray. Ten plants from each treatment were randomly selected and planted in the field at the Univ. of Arkansas Fruit Substation, Clarksville, on 3 Oct. 1992. The soil was a Linker sandy loam (Typic Hapludults) with $\mathrm{pH} 6.1$ and $0.8 \%$ organic matter. All plants were planted at $20 \times$ 20-cm spacing. Urea, at $43 \mathrm{~kg} \cdot \mathrm{ha}^{-1}$, was applied on 1 Nov. 1992. The SAS general linear model procedure was used to analyze the data and perform the regression analysis (SAS Inst., Cary, N.C.).

Infection determination. The roots were

Production of pot-cultured inoculum. The endophyte Glomus intraradices was used as the fungal inoculum. Plastic pots $\left(3000 \mathrm{~cm}^{3}\right)$ were filled with sterilized masonry sand and mixed with $0.2 \mathrm{~g}$ of Osmocote $17 \mathrm{~N}-9 \mathrm{P}-13 \mathrm{~K}$ ( 3 to 4 months release rate) fertilizer/L (GraceSierra, Houston). Each container was inoculated with $4 \mathrm{~g}$ of inoculum of glomus (1000 spores/g), and 50 sorghum (Sorghum vulgare L.) seeds were planted in each container. The pots were kept in the greenhouse at 25 to $32^{\circ} \mathrm{C}$ and water was applied as needed. The sorghum was grown for 6 months and application of water was reduced in the final 3 weeks to maximize spore production (Menge, 1982). After 6 months, plants were cut near the base cleared by boiling them in $10 \%$ potassium hydroxide solution. Trypan blue $(0.25 \mathrm{~g})$ was mixed with $250 \mathrm{~mL}$ of lactophenol (Phillips and Hayman, 1970). Roots were submerged in this $0.1 \%$ solution, autoclaved at $101{ }^{\circ} \mathrm{C}$ and 1 MPa for $3 \mathrm{~min}$, and then washed with water and autoclaved in an additional lactophenol solution for $3 \mathrm{~min}$. The roots were washed and spread out evenly in petri dishes marked with 2.5 -cm grids. The percent infection was determined using the gridline intersect method (Giovannetti and Mosse, 1980).

Plant measurements. In the greenhouse, the number of plants having four, five, six, or seven leaves was counted on all seedlings at 
24, 34, 44, and 54 days after planting (DAP), respectively (i.e., having four leaves at 24 days, five leaves at 34 days, etc.). Plant height was determined on 15 randomly selected plants for each treatment at 34,51, and 68 days DAP. On day 90, plants from all treatments were harvested, and 15 randomly selected plants were oven-dried at $80^{\circ} \mathrm{C}$ for 4 days and total dry weight was determined.

In the field, percent stand was determined for all treatments on 11 Apr. 1993, and for six randomly selected plants per treatment, the number of leaves per plant was counted on 26 May 1993. Leaf area (mother plant plus runner), measured with a leaf area meter (Lambda Instrument Corp., Lincoln, Neb.), and the number of runner plants per mother plant were determined on 5 June 1993 on five randomly selected plants in each treatment. Four randomly selected plants (mother plant plus runner) were destructively harvested on 5 June, oven-dried at $80^{\circ} \mathrm{C}$ for 4 days, and dry weights recorded.

Incidence of root infection was determined on 1 Oct. 1992 and 5 June 1993 by random sampling of five and 10 plants, respectively, from each noninoculated (control) treatment replication and pooling the roots within a replication. For each inoculated treatment, four root samples per replication were pooled and incidence of infection determined. Foliar nutrient analyses were conducted on nonsenescent, fully expanded leaves for four randomly sampled plants from each inoculated treatment and for five plant samples pooled for each control treatment replication. Leaf samples were oven-dried at $80^{\circ} \mathrm{C}$ for 3 days, then ground using a Wiley mill (Arthur Thomas, Philadelphia) to pass through a 16-mesh (1.02-mm pores) screen. Total $\mathrm{N}$ was determined with the combustion method using a Leco FP228 (Leco, St. Joseph, Mich.) N determinator. All other elements were determined by inductively coupled plasma spectrometry following $\mathrm{HNO}_{3}$ digestion. Samples were analyzed at the Agricultural Services Laboratory, Dept. of Agronomy, Univ. of Arkansas, Fayetteville.

\section{Results}

\section{Greenhouse studies}

Leaf growth. Some mycorrhizal plants had more leaves per plant than nonmycorrhizal plants at each examination (DAP) (Fig. 1). At 24 DAP, inoculation with 1500 or 3000 spores resulted in more plants that had four leaves compared to SD of 0,7500 , or 12,000 . At 34 DAP, the 1500 SD resulted in more plants with five leaves than 0 or $12,000 \mathrm{SD}$. The 750 and $3000 \mathrm{SD}$ also were superior to the control. At 44 DAP, the 1500 SD was superior to 0,7500 , and $12,000 \mathrm{SD}$. The $3000 \mathrm{SD}$ was associated with more plants with six leaves than the control at this date. On the final measurement date (54 DAP), plants with seven leaves were more common with 750,1500 , and 3000 SD than with the control. There was a significant quadratic relationship between SD and the number of plants that had four, five, six, or

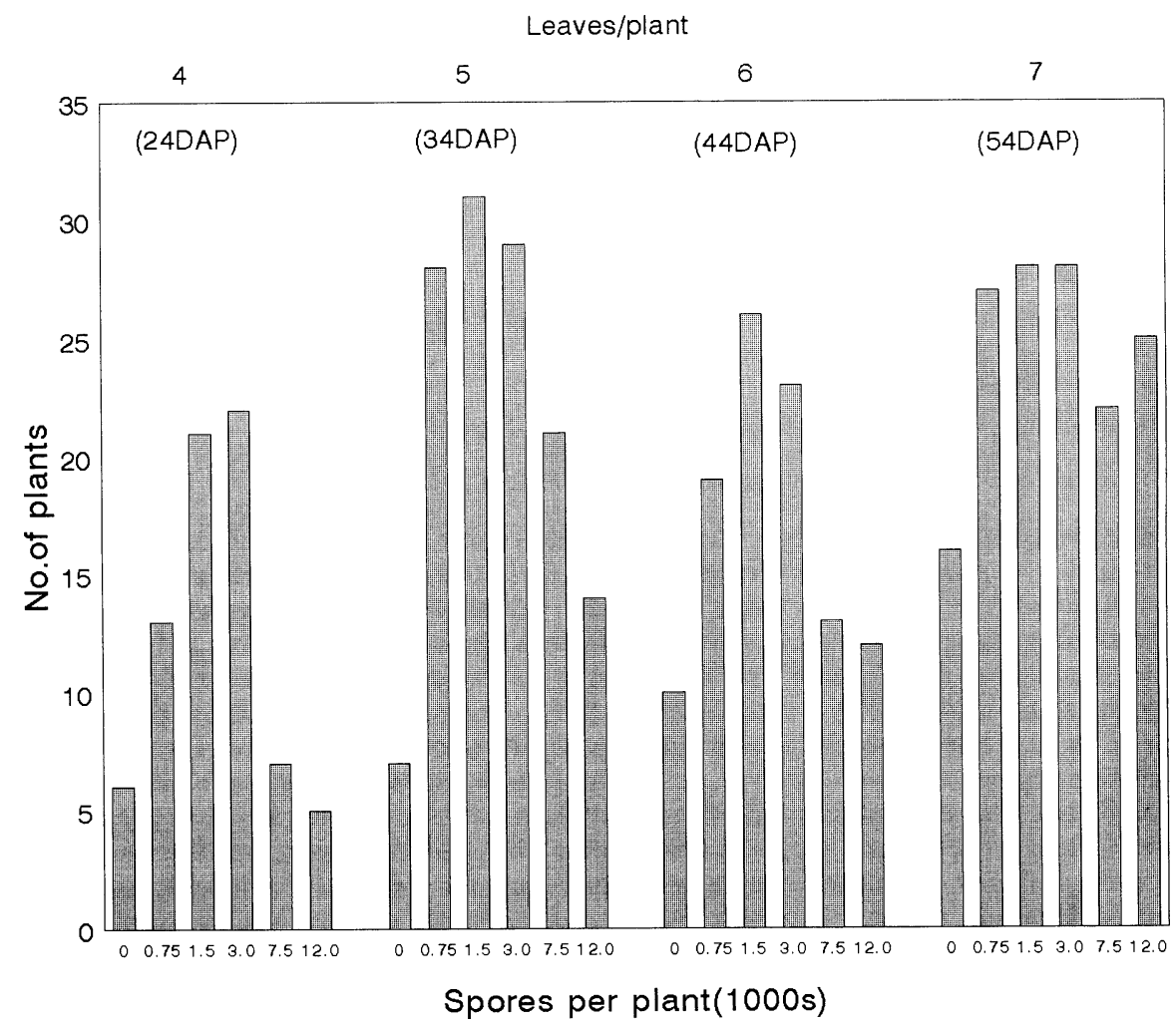

Fig 1. Influence of spore density on leaf production by 'Sweetheart' strawberry seedlings. Plants with four, five, six, and seven leaves determined at $24,34,44$, and 54 days, respectively (i.e., four leaves at 24 days, five leaves at 34 days, etc.). Quadratic regression $24 \mathrm{DAP}, \mathrm{Y}=6.35+8.6 \mathrm{X}-1.4 \mathrm{X}^{2} ; 34 \mathrm{DAP}, \mathrm{Y}=7.94$ $+14.1 \mathrm{X}-2.19 \mathrm{X}^{2} ; 44 \mathrm{DAP}, \mathrm{Y}=10.47+8.43 \mathrm{X}-1.40 \mathrm{X}^{2} ; 54 \mathrm{DAP}, \mathrm{Y}=16.59+6.41 \mathrm{X}-0.88 \mathrm{X}^{2} ;$ significant at $P \leq 0.01 ; \mathrm{n}=4$ with 50 subsamples.

seven leaves at $24,34,44$, and $54 \mathrm{DAP}(P \leq$ $0.01)$.

Seedling height. At 51 and 68 days, inoculated plants were taller than control plants (Table 1), but there was no effect of inoculum SD on plant height $(P>0.05)$, and there was a significant interaction between mycorrhizal inoculation and measurement dates for seedling height $(P<0.01)$ (Table 1$)$.

Drymatter production. Mycorrhizal strawberry seedlings produced significantly more total dry weight than the controls $(P<0.01)$, and there was a linear positive relationship between total dry weight of inoculated seedlings and $\mathrm{SD}(P \leq 0.0001)$ (Table 2$)$. However, the nonlinear components were nonsignificant for the mycorrhizal seedlings $(P>0.05)$.

\section{Field studies}

At the time of removal from the greenhouse, the two highest SD (7500 and 12,000) resulted in the highest infection incidences (Table 3). At the time of removal from the field, these same treatments resulted in infection rates of $\approx 60 \%$, while the infection was slightly higher, and equal, with 750 and 1500 spores/plant. One-third of the control plants were infected with indigenous mycorrhiza. There was a linear relationship between SD and percent infection at the time of removal from the greenhouse; however, at removal from the field, there was a cubic relationship between SD and percent infection $(P=0.02)$.

Mycorrhizal infection had no effect on plant survival $(P>0.05)$, which ranged from $80 \%$ to $95 \%$, but inoculated strawberry plants had significantly more leaves, larger leaf area, and more runners per plant than the controls $(P$ $<0.01$ ) (Table 4).

The concentrations of major and most of the minor nutrients in leaves were similar for inoculated and the control plants. However, there was a linear relationship between spore density and $\mathrm{Ca}$ and $\mathrm{Cu}$ concentrations; but the nonlinear components were nonsignificant $(P$ $>0.05$ ) (Table 5). Root dry weights decreased linearly with increasing SD $(P=0.03)$. The

Table 1. Analysis of variance of greenhouse-grown mycorrhizal and nonmycorrhizal strawberry seedling height at 34,51 , and 68 days.

\begin{tabular}{lcc}
\hline \hline & \multicolumn{2}{c}{ Mean seedling ht $(\mathrm{cm})$} \\
\cline { 2 - 3 } Treatment & Inoculated & Control \\
\hline Days & $1.07 \pm 0.54^{\mathrm{z}}$ & $0.80 \pm 0.42^{\mathrm{z}}$ \\
34 & $2.31 \pm 0.92$ & $1.56 \pm 0.71$ \\
51 & $3.70 \pm 0.94$ & $2.44 \pm 0.88$ \\
68 & $2.36 \pm 0.06$ & $1.60 \pm 0.06$ \\
Mean & \\
Significance & \\
$\quad$ Treatment $($ Trt $)$ & \\
$\quad$ Inoculated $\times$ & \\
$\quad$ noninoculated) & $0.0001^{* * *}$ \\
Spore density & $0.66^{\mathrm{Ns}}$ \\
Trt $\times$ spore density & $0.54^{\mathrm{Ns}}$ \\
Trt $\times$ day & $0.0001^{* * *}$ \\
Spore density $\times$ day & $0.63^{\mathrm{Ns}}$ \\
\hline
\end{tabular}

${ }^{\mathrm{2} \text { Means } \pm \text { SE. }}$

Ns, *** Nonsignificant or significant at $P \leq 0.001$, respectively; $n=4$, with 15 subsamples per replication. 
Table 2. Effect of mycorrhizal spore density on total dry matter of greenhouse-grown 'Sweetheart' strawberry seedlings 90 days after planting.

\begin{tabular}{lc}
\hline $\begin{array}{l}\text { Spore density } \\
\text { (no./plant) }\end{array}$ & $\begin{array}{c}\text { Total dry wt } \\
(\mathrm{g})^{\mathrm{z}}\end{array}$ \\
\hline 0 & 1.45 \\
750 & 2.01 \\
1,500 & 2.10 \\
3,000 & 2.33 \\
7,500 & 2.50 \\
12,000 & 3.50 \\
Significance & \\
$\quad$ Inoculated vs. & \\
$\quad$ noninoculated & $* *$ \\
$\quad$ Spore density & \\
$\quad$ Linear & \\
$\quad$ Quadratic & 0.0001 \\
Cubic & 0.08 \\
\end{tabular}

${ }^{\mathrm{z}} \mathrm{n}=4$, with 15 subsamples per replication.

*** Significant at $P \leq 0.01$.

Table 3. Infection percentage of 'Sweetheart' strawberry seedlings inoculated with Glomus intraradices. $^{2}$

\begin{tabular}{lcc}
\hline $\begin{array}{l}\text { Spore density } \\
\text { (no./plant) }\end{array}$ & \multicolumn{2}{c}{ Infection(\%) at removal from } \\
\cline { 2 - 3 } & Greenhouse & Field $^{\mathrm{x}}$ \\
\hline 0 & 0 & 33 \\
150 & 45 & 65 \\
1,500 & 50 & 65 \\
3,000 & 59 & 59 \\
7,500 & 62 & 56 \\
12,000 & 72 & 60 \\
Significance & & \\
$\quad$ Linear & 0.001 & 0.28 \\
Quadratic & 0.302 & 0.16 \\
Cubic & 0.114 & 0.02 \\
\hline
\end{tabular}

${ }^{2}$ Four subsamples from each replication were taken for infection measurement for inoculated treatments. yPercent infection was estimated on greenhousegrown seedlings on 1 Oct. 1992, 90 days after planting. Control treatments were pooled with five root samples per replication.

xPercent infection was estimated on field-grown plants 1 day after removal from the field. Control treatments were pooled with 10 root samples per replication.

most dry matter per plant was obtained with the 750 spores per plant (Table 6), and inoculated plants produced significantly higher shoot and root dry matter than noninoculated controls $(P<0.01)$. Inoculated strawberry plants had significantly higher root: shoot ratios than the controls $(P<0.01)$; moreover, a significant quadratic relationship existed between SD and the root : shoot ratio (Table 6).

\section{Discussion}

The mycorrhizal fungus $G$. intraradices increased strawberry plant growth in the greenhouse and in the field compared to noninoculated plants. These results corroborate other findings with strawberries (Holevas, 1966; Kiernan et al., 1984; Robertson et al., 1988). In the greenhouse, infection of $G$. intraradices increased linearly with increasing inoculum density. Although it has been reported that 100 spores of Glomus E3 per strawberry plant resulted in a $70 \%$ infection rate (Koomen et al., 1987), we found that 12,000 spores per plant resulted in a similar infection rate. However, after field-planting, the infection rates for all
Table 4. Growth response of field-grown 'Sweetheart' strawberry seedlings infected with various spore densities.

\begin{tabular}{lccc}
\hline $\begin{array}{l}\text { Spore density } \\
\text { (no./plant) }\end{array}$ & $\begin{array}{c}\text { Leaf } \\
\text { count }^{\mathrm{z}}\end{array}$ & $\begin{array}{c}\text { Leaf area } \\
\left(\mathrm{cm}^{\mathrm{y}}\right)\end{array}$ & $\begin{array}{c}\text { Runners } \\
(\text { no. })^{\mathrm{x}}\end{array}$ \\
\hline 0 & 4.2 & 136 & 6.1 \\
750 & 5.4 & 168 & 6.1 \\
1,500 & 5.1 & 197 & 7.2 \\
3,000 & 5.3 & 196 & 7.1 \\
7,500 & 5.1 & 194 & 6.8 \\
12,000 & 5.1 & 158 & 6.6 \\
Significance & & & \\
$\quad$ Inoculated vs. & & & \\
$\quad$ noninoculated & $* *$ & $* *$ & \\
$\quad$ Spore density & & & \\
$\quad$ Linear & 0.38 & 0.25 & 0.92 \\
$\quad$ Quadratic & 0.81 & 0.06 & 0.43 \\
$\quad$ Cubic & 0.83 & 0.54 & 0.27 \\
\hline
\end{tabular}

${ }^{\mathrm{z}}$ Six subsamples per replication counted on 26 May. y Two subsamples per replication counted on 5 June. ${ }^{x}$ Five subsamples per replication counted on 5 June. *** Significant at $P \leq 0.01$.

Table 5. Concentration of $\mathrm{Ca}$ and $\mathrm{Cu}$ in leaves of field-grown 'Sweetheart' strawberry seedlings.

\begin{tabular}{lcc}
\hline \hline $\begin{array}{l}\text { Spore density } \\
\text { (no./plant) }\end{array}$ & \multicolumn{2}{c}{ Foliar elements (dry wt basis) } \\
\cline { 2 - 3 } & $\mathrm{Ca}(\%)$ & $\mathrm{Cu}\left(\mathrm{mg} \cdot \mathrm{kg}^{-1}\right)$ \\
\hline 0 & 1.0 & 4.2 \\
750 & 1.0 & 3.7 \\
1,500 & 1.0 & 4.2 \\
3,000 & 1.2 & 5.0 \\
7,500 & 1.2 & 4.0 \\
12,000 & 1.5 & 7.5 \\
Significance & & \\
$\quad$ Spore density & & \\
$\quad$ Linear & 0.02 & 0.02 \\
$\quad$ Quadratic & 0.90 & 0.20 \\
$\quad$ Cubic & 0.44 & 0.16 \\
\hline Foliar samples
\end{tabular}

${ }^{\mathrm{z} F o l i a r}$ samples collected from four subsamples per replication. Five plant subsamples from each control treatment were pooled per replication.

treatments were similar. This agrees with findings reported on infection of strawberry by $G$. intraradix V18 and G. intraradix V20 (Vestberg, 1992a).

Although Niemi and Vestberg (1992) obtained no differences in total shoot and root biomass between controls and mycorrhizal plants in micropropagated seedling strawberries, enhanced dry matter production has been reported with Glomus spp. CPH-23 on micropropagated strawberry (Chavez and Ferrera-Cerrato, 1990). In our greenhouse study, mycorrhizal plants at the highest inoculum level produced $70 \%$ more total dry matter than the controls. In a field study, Robinson (1984) observed no growth differences between inoculated and noninoculated strawberry plants. The findings of our field study corroborate findings of Vestberg (1992a) and Niemi and Vestberg (1992) in which mycorrhizal strawberry transplants that were growing in the field grew better than the control plants.

Foliar nutrient concentration in shoots of mycorrhizal plants showed a linear relationship for $\mathrm{Ca}$ and $\mathrm{Cu}$ with increasing spore density. However, control plants and mycorrhizal plants had similar amounts of other elements, possibly as a result of infection by indigenous mycorrhiza in the controls. In- creased growth of inoculated plants could have been due to increased speed of regrowth (Barrows and Roncadori, 1977) or reduced disease incidence from soilborne pathogens (Schenck and Kellam, 1978). As in other studies (Hrselova et al., 1989; Niemi and Vestberg, 1992; Vestberg, 1992b), mycorrhizal plants produced more runner plants than the controls.

In our study, higher root : shoot ratios for mycorrhizal plants could be due to higher root dry weight of mycorrhizal than nonmycorrhizal plants, although this is contrary to the results of Kiernan et al. (1984), who found a higher root : shoot ratio in nonmycorrhizal than in mycorrhizal strawberry plants. Control plants, although colonized with indigenous mycorrhiza, did not have more root dry matter than mycorrhizal strawberry plants. Although infected with indigenous mycorrhiza, control plants had less root infection than the inoculated plants, which agrees with a study by Vestberg (1992a), also on strawberry. There was no correlation between percent infection and growth. Similar findings have been reported by Williams et al. (1992) and Koomen et al.(1987). Indigenous mycorrhiza may have influenced the growth of strawberry plants in the control (Powell, 1981). However, inoculated plants may have had an advantage over the indigenously infected plants since they were already colonized before planting (LopezAguillon and Mosse, 1987). Contrary to findings by Vestberg (1992a), overwintering did not decrease the ability of introduced fungus to increase growth of the plants in our studies.

Biermann and Linderman (1983) reported that pretransplant inoculation could permit selection and establishment of more efficient strains of mycorrhiza that could colonize new roots after plant establishment. Exposing seedlings in seedling flats to VAM infection would tend to equalize VAM infection before field planting. Thus, in the field all seedlings would be more nearly equal in VAM, whereas indigenous VAM infection in nonfumigated soils would be variable. In a nonfumigated soil, pathogenic fungi or low seedling vigor in plants after seedling establishment may result in these plants being discarded at selection, thus leading to the loss of a superior genotype (J.N. Moore, personal communication). Seedling diseases caused by plant pathogenic fungi could be overcome by VAM, which could thus increase the chances of selecting a desired genotype in a breeding program. Our study demonstrates that it is possible to introduce a mycorrhizal fungus into strawberry roots via seed bed application. A spore density of 750 spores/plant was sufficient for a positive growth response in nonsterilized preinoculated soil.

\section{Literature Cited}

Barrows, J.B. and R.W. Roncadori. 1977. Endomycorrhizal synthesis by Gigaspora margarita in poinsettia. Mycologia 69:11731184.

Biermann, B.J. and R.G.Linderman. 1983. Increased geranium growth using pretransplant inoculation with a mycorrhizal fungus. J. Amer. Soc. Hort. Sci. 108:972-976.

Chavez, M.C.G. and R. Ferrera-Cerrato. 1990. Ef- 
Table 6. Effect of mycorrhizal spore density on strawberry plant dry weight and root : shoot ratio of fieldgrown 'Sweetheart' strawberry plants.

\begin{tabular}{llllc}
\hline \hline $\begin{array}{l}\text { Spore density } \\
\text { (no./plant) }\end{array}$ & \multicolumn{3}{c}{ Dry wt $(\mathrm{g})^{\mathrm{z}}$} & \\
\cline { 2 - 4 } & Shoot & Root & Total & Root : shoot \\
\hline 0 & 15.5 & 1.2 & 16.7 & 0.009 \\
750 & 28.1 & 2.5 & 30.6 & 0.014 \\
1,500 & 26.6 & 2.9 & 29.5 & 0.015 \\
3,000 & 28.0 & 2.4 & 30.4 & 0.012 \\
7,500 & 22.1 & 1.5 & 23.6 & 0.008 \\
12,000 & 22.6 & 2.1 & 24.7 & 0.014 \\
Significance & & & & $*$ \\
$\quad$ Inoculated vs. & $* *$ & $* *$ & $* *$ & \\
$\quad$ noninoculated & & & & 0.43 \\
$\quad$ Spore density & 0.10 & 0.03 & 0.08 & 0.02 \\
$\quad$ Linear & 0.66 & 0.09 & 0.56 & 0.48 \\
$\quad$ Quadratic & 0.55 & 0.26 & 0.49 & \\
$\quad$ Cubic & & & & \\
\hline
\end{tabular}

${ }^{\mathrm{z}}$ Four subsamples per replication measured on 5 June.

*,**Significant at $P \leq 0.05$ or 0.01 , respectively.

fect of vesicular-arbuscular mycorrhizae on tissue culture derived plantlets of strawberry. HortScience 25:903-905.

Daft, M.J. and T.H. Nicolson. 1966. Effect of endogone mycorrhiza on plant growth. New Phytol. 65:343-350.

Daft, M.J. and T.H. Nicolson. 1969. Effect of endogone mycorrhizae on plant growth. 111 Influence of inoculum concentration on growth and infection of tomato. New Phytol. 68:953963.

Daft, M.J. and B.O. Okusanya. 1973. Effect of endogone mycorrhizae on plant growth. VI. Influence of infection on the anatomy and reproductive development in four hosts. New Phytol. 72:1333-1339.

Diem, H.G., I. Gueye, V. Gianinazzi-Pearson, J.A. Fortin, and Y.R. Dommergues. 1981. Ecology of VA vesicular-arbuscular mycorrhizae in the tropics: The semi arid zone of Senegal. Acta. Oecol. 2:53-61.

Dunne, M.J. and A.H. Fitter. 1989. The phosphorus budget of a field-grown strawberry (Fragaria $\times$ ananassa cv. Hapil) crop: Evidence for a mycorrhizal contribution. Ann. Appl. Biol. 114:185193.

Gerdemann, J.W. and T.A. Nicolson. 1963. Spores of mycorrhizal endogone species extracted from soil by wet sieving and decanting. Trans. Brit. Mycol. Soc. 46:235-244.

Giovannetti, M. and B. Mosse. 1980. An evaluation of techniques for measuring vesicular-arbuscular mycorrhizal infection on roots. New Phytol. 84:489-500.

Holevas, C.D. 1966. The effect of vesicular- arbuscular mycorrhiza on uptake of soil phosphorus by strawberry. J. Hort. Sci. 41:57-64.

Hrselova, H., M. Gryndler, and V. Vancura. 1989. Influence of inoculation with vesiculararbuscular mycorrhizal fungus species on growth of strawberries and runner formation. Agr., Ecosystems \& Environ. 39:193-197.

Khan, A.G. 1972. The effect of vesicular-arbuscular mycorrhizal associations on growth of cereals. 1. Effects on maize growth. New Phytol. 71:613619.

Kiernan, J.M., J.W. Hendrix, L.P. Stoltz, and D.M. Maronek. 1984. Characterization of strawberry plants produced by tissue culture and infected with specific mycorrhizal fungi. HortScience 19:883-885.

Koide, R. and X. Lu. 1992. Mycorrhizal infection of wild oats: Parental effects on offspring nutrient dynamics, growth and reproduction, p. 55-57. In: D.J. Read, D.H. Lewis, A.H. Fitter, and I.J. Alexander (eds.). Mycorrhizas in ecosystems. CAB Intl., U.K.

Koomen, I., C. Grace, and D.S. Hayman. 1987. Effectiveness of single and multiple mycorrhizal inocula on growth of clover and strawberry plants at two soil pHs. Soil Biol. Biochem. 19:539-544.

Larson, K. and D.V. Shaw. 1995. Relative performance of strawberry genotypes on fumigated and non-fumigated soils. J. Amer. Soc. Hort. Sci. 120:274-277.

Lopez-Aguillon, R. and B. Mosse. 1987. Experiments on competitiveness of three endomycorrhizal fungi. Plant \& Soil 97:155-170.

Maas, J.L. 1984. Compendium of strawberry dis- eases. APS Press, St. Paul, Minn.

Maronek, D.M., J.W Hendrix, and J. Kiernan. 1981. Mycorrhizal fungi and their importance in horticultural crop production. Hort. Rev. 3:172213.

Menge, J.A. 1982. Utilization of vesiculararbuscular mycorrhizal fungi in agriculture. Can. J. Bot. 61:1015-1024.

Nemec, S. 1983. Inoculation of citrus in the field with vesicular-arbuscular mycorrhizal fungi in Florida. Trop. Agr. 60:97-101.

Niemi, M. and M. Vestberg. 1992. Inoculation of commercially grown strawberry with VA mycorrhizal fungi. Plant \& Soil 144:133-142.

Philips, J.M. and D.S. Hayman. 1970. Improved procedures for cleaning roots and staining parasitic and vesicular-arbuscular mycorrhizal fungi for rapid assessment of infection. Trans. Brit. Mycol. Soc. 55:158-160.

Powell, C.L.I. 1981. Effects of inoculum rate on mycorrhizal growth responses in pot grown onion and clover. Plant \& Soil 62:231-239.

Robertson, W.J., C.D. Boyle, and H.D. Brown. 1988. Endomycorrhizal status of certified strawberry nursery stock. J. Amer. Soc. Hort. Sci. 113:525-529.

Robinson, J.D. 1984. Effect of vesicular arbuscular mycorrhizal fungi on strawberry daughter establishment and early growth. MS Thesis, Clemson Univ., Clemson, S.C.

Ross, J.P. and J.A. Harper. 1970. Effects of endogone mycorrhiza on soybean yields. Phytopathology 60:1552-1556.

SAS Institute. 1985. SAS user's guide. SAS Inst., Cary, N.C.

Schenck, N.E. and M.K. Kellum. 1978. The influence of vesicular-arbuscular mycorrhizae on disease development. Florida Agr. Expt. Sta. Bul. 798.

Solbrig, O.T. 1981. Studies on the population biology of the genus viola. 11. The effect of plant size on fitness in Viola sororia. Evolution 35:1080-1094.

Vestberg, M. 1992a. Arbuscular mycorrhizal inoculation of micropropagated strawberry and field observations in Finland. Agronomie 12:865867.

Vestberg, M. 1992b. The effect of vesiculararbuscular mycorrhizal inoculation on the growth and root colonization of ten strawberry cultivars. Agr. Sci. Fin. 1:527-534.

Williams, S.C.K., M. Vestberg, M. Uosukainen, J.C. Dodd, and P. Jeffries. 1992. Effects of fertilizers and arbuscular mycorrhizal fungi on the post-vitro growth of micropropagated strawberry. Agronomie 12:851-857. 